\title{
THE POWER TO SHAPE THE INTERNAL MARKET: IMPLICATIONS OF CJEU CASE LAW FOR THE EU'S INSTITUTIONAL BALANCE
}

\author{
Vilija Velyvyte
}

\begin{abstract}
Summary: This paper is concerned with the implications of CJEU internal market case law for the balance of powers between the EU institutions. It argues that the Court's case law involving the areas of domestic policy reserved by the Treaty predominantly for the competence of the Member States creates an inter-institutional dynamic that restrains the rule-making capacity of the EU legislature. This dynamic seems to undermine the EU law principle of institutional balance because it either (i) prevents EU-level legislative action, or (ii) predetermines its content, or (iii) makes it devoid of practical force through expansive judicial interpretation of secondary legislation.
\end{abstract}

\section{Introduction}

The reach of EU law is wider in scope than the EU's legislative competence because Member States must ensure compliance with EU free movement and competition rules, which are interpreted and applied by the CJEU (or 'the Court'), even in policy areas that fall outside the EU legislative competence. This situation seems to create a constitutional asymmetry of powers ${ }^{1}$ between the EU legislature and the judiciary. This paper aims to show how this asymmetry plays out in practice. It argues that the Court's case law creates an inter-institutional dynamic that seems to undermine the EU law principle of institutional balance.

This argument is based on an analysis of EU-level legislative developments (or a lack thereof) taking place in light of the Court's internal market case law involving two areas of domestic social policy which in principle fall outside EU legislative competence - healthcare and collective labour law. ${ }^{2}$ Despite the Treaty stipulations asserting the prerogative

DPhil in Law Candidate, Brasenose College, University of Oxford.

\footnotetext{
1 J Weiler, 'The Dual Character of Supranationalism' (1981) 1 YEL 267; F Scharpf, 'The Asymmetry of European Integration or Why the EU Cannot Be a "Social Market Economy" (2009) KFG Working Paper Series, No 6, Kolleg-Forschergruppe (KFG) The Transformative Power of Europe, Free University Berlin <http://www.polsoz.fu-berlin.de/en/v/transformeurope/publications/working_paper/WP_06_September_Scharpf1.pdf> accessed 14 June 2016.

2 Given the interchangeability in the usage of the terms 'labour' and 'employment' law in some of the academic literature, the author uses the term 'collective labour law' to refer to
} 
of the Member States to regulate the two policy areas and the explicit exclusion of harmonisation under the respective sectoral legal bases, ${ }^{3}$ both healthcare and collective labour law have been substantially influenced by EU law through the judgments of the CJEU interpreting free movement and competition rules. ${ }^{4}$ The free movement case law has attracted particular criticism. The Court's elaborate definition of the 'medical necessity' test employed in cases concerning the reimbursement of costs of medical treatment obtained abroad has been criticised for depriving Member States of their autonomy to manage national healthcare budgets independently and thus threatening to undermine public policies which seek to prioritise patients in most need of care. ${ }^{5}$ Similarly, the Court's interpretation of the relationship between collective labour rights and economic freedoms has been widely claimed to constrain the operational autonomy of trade unions, thus challenging the viability of domestic systems of industrial relations. ${ }^{6}$ Moreover, as a result of the case law, a number of social policy issues pertaining to healthcare and collective labour law have been removed from the national regulatory domain, thus increasing the role of EU judicial law-making.

Whilst recognising the implications of the case law for national regulatory systems, this paper focuses on a less discussed aspect surround-

collective aspects of labour law, as opposed to the individual ones, also known as employment law.

3 Consolidated Version of the Treaty on the Functioning of the European Union [2008] OJ C115/49 (TFEU) arts 153, 168.

4 For similar developments, see the case law on cross-border access to education, eg Case C-73/08 Bressol and Chaverot [2009] ECR I-2782, Opinion of AG Sharpston, para 20; AP Van der Mei, 'Free Movement of Students and the Protection of National Educational Interests: Reflections on Bressol and Chaverot' (2011) 13 Eur J Migration and L 123. See also the case law on sports, eg Case C-415/93 Union Royale Belge Sociétés de Football Association and Others v Bosman [1995] ECR I-4921; SR Weatherill, 'Bosman Changed Everything: The Rise of EC Sports Law' in M Poiares Maduro and L Azoulai (eds), The Past and Future of EU Law: The Classics of EU Law Revisited on the 50th Anniversary of the Rome Treaty (Hart Publishing 2010).

5 Case C-372/04 Yvonne Watts v NHS [2006] ECR I-4325 (Watts); C Newdick, 'Citizenship, Free Movement, and Healthcare: Cementing Individual Rights by Corroding Social Solidarity' (2006) 43 CML Rev 1645, 1650; D Schiek, 'The EU Constitution of Social Governance in an Economic Crisis in Defence of a Transnational Dimension to Social Europe' (2013) 20 MJ 195; G Davies, 'The Process and Side-Effects of Harmonisation of European Welfare States' (2006) NYU Jean Monnet Program Working Paper 2/2006 < http://www.jeanmonnetprogram.org/papers/06/060201.pdf> accessed 7 June 2014.

6 Case C-438/05 International Transport Workers' Federation and Finnish Seamen's Union $v$ Viking Line [2007] ECR I-10779 (Viking); Case C-341/05 Laval v Svenska Byggnadsarbetareförbundet [2007] ECR I-11767 (Laval); Case C-426/11 Mark Alemo-Herron and Others $v$ Parkwood Leisure Ltd [2013] ECR 00000 (Alemo-Herron); ACL Davies, 'Should the EU Have the Power to Set Minimum Standards for Collective Labour Rights in the Member States?' in P Alston (ed), Labour Rights as Human Rights (OUP 2005) 206-207; ACL Davies, 'One Step Forward, Two Steps Back? The Viking and Laval Cases in the ECJ' (2008) 37 ILJ 126, 143; KD Ewing and J Hendy QC, 'The Dramatic Implications of Demir and Baykara' (2010) 39 ILJ 2, 13. 
ing the case law, namely, how judicial developments have affected the institutional relationship between the CJEU and the EU's legislature - the Commission, the Parliament, and the Council. The paper is divided into four sections. Following this Introduction, Section 2 outlines the main developments in CJEU case law concerning the intersection of the free movement rules, on the one hand, and healthcare and collective labour rights, on the other. It also discusses the implications of the case law for the regulatory capacity of the Member States. Section 3 introduces the concept of institutional balance as a constitutional principle of EU law. Section 4 discusses three ways in which the Court's practice is liable to upset this principle. First, the Court's judgments may prevent legislative action at the EU level. Second, the legislature is often incapable of reversing the effects of the case law due to the expansive and detailed judicial interpretations of secondary legislation in light of the free movement rules. Third, the case law often serves to determine the content of EU legislative action. Section 5 concludes.

\section{CJEU case law and its implications for national regulatory systems}

\subsection{Patient mobility: less room for national autonomy - better healthcare for EU citizens?}

According to EU rules on cross-border healthcare, as interpreted in the case law of the CJEU, any outpatient care to which a patient is entitled under the social security scheme in her home Member State may also be obtained in any other Member States without prior authorisation and be reimbursed up to the level of reimbursement provided by the patient's home state. ${ }^{7}$ Any inpatient, or hospital, care to which a patient is entitled in her home MS may also be obtained elsewhere in the EU, provided that the patient has been granted prior authorisation by the authorities in the home Member State. This authorisation must be given if the healthcare system to which the patient is affiliated cannot provide equally effective treatment within a medically acceptable time limit. In determining whether a treatment which is equally effective can be obtained within an acceptable time, national authorities must take into account the circumstances pertaining to the medical situation and the clinical needs of the person concerned, such as the history, probable course of her illness, and degree of pain or the nature of disability at the time when the request for authorisation was made or renewed. ${ }^{8}$ If authorisation is granted or

\footnotetext{
7 Case C-120/95 Nicolas Decker v Caisse de maladie des employés privés [1998] ECR I-01831 (Decker); Case C-158/96 Raymond Kohll v Union des caisses de maladie [1998] ECR I-01931 (Kohll); Case C-385/99 Müller-Fauré [2003] ECR I-4509.

8 Case C-157/99 Geraets-Smits and Peerbooms [2001] ECR I-5473, paras 53-55; MüllerFauré (n 7) paras 89-90; Watts (n 5) paras 59-61.
} 
has been unlawfully refused, the patient is entitled to full reimbursement of the costs of treatment received abroad, determined in accordance with the tariff set by the host state. ${ }^{9}$

Essentially every judgment of the CJEU involving cross-border healthcare starts with the recognition, in accordance with article 168(7) TFEU, that the EU's action in the field of public health has to respect fully the responsibilities of the Member States for the organisation and delivery of health services and medical care. In the absence of EU level harmonisation in the field, it is for the legislation of each Member State to determine the personal scope, conditions of entitlement and range of benefits. ${ }^{10}$ At the same time, article 168(7) does not exclude the possibility that Member States may be required under other Treaty provisions, such as the free movement rules, or measures adopted on the basis of these provisions, such as article 22 of Regulation 883/2004 on the coordination of national social security systems, ${ }^{11}$ to make adjustments to national social security systems. These necessary adjustments do not, however, undermine Member States' sovereign powers in the field. ${ }^{12}$

In line with this logic, the Court emphasises that its interpretation of conditions for obtaining treatment abroad in light of EU free movement rules aims to balance EU citizens' right to cross-border health with national concerns relating to the sustainability and financial stability of their social security systems. ${ }^{13}$ This balance is to be achieved by drawing a distinction between, on the one hand, reasonable waiting time for receiving medical treatment in the home state and, on the other hand, undue delay, or medically unjustifiable waiting time. If the waiting time is reasonable, the fact that equally effective treatment is available more quickly in another Member State does not suffice to challenge a decision to refuse authorisation (and consequently claim reimbursement of the costs of treatment received abroad). Otherwise, patient migration would be liable to put at risk governments' planning and rationalisation efforts in the healthcare sector, which could create problems of hospital overcapacity, imbalance in the supply of hospital medical care, and logistical and financial wastage. ${ }^{14}$ However, where the waiting time for adequate treatment in the home state exceeds medically justifiable time, according to the interpretation of this concept provided by the Court, the granting

\footnotetext{
9 Note that reimbursement will be calculated in accordance with the tariff of the home Member State when the claim is not based on Regulation (EC) No 883/2004 of the European Parliament and of the Council of 29 April 2004 on the coordination of social security systems [2004] OJ L166/1 (Regulation 883/2004).

10 See eg Smits and Peerbooms (n 8) para 45.

11 Regulation 883/2004 (n 9).

12 Watts (n 5) para 121.

13 Watts (n 5) para 145; Smits and Peerbooms (n 8) paras 76, 78-79.

14 Smits and Peerbooms (n 8) para 106; Müller-Fauré (n 7) para 91; Watts (n 5) para 71.
} 
of authorisation and subsequent reimbursement of costs are not considered to be liable to jeopardise the sustainability of hospital care. ${ }^{15}$

The position adopted by the Court does not seem to reflect the realities of the operation of the healthcare sector and does in fact threaten to jeopardise the financial sustainability of the national healthcare systems, thus affecting the accessibility and quality of healthcare. In particular, the Court's interpretation of what constitutes a medically necessary treatment seems to undermine public policies which seek to prioritise patients in most need of care. The medical necessity test is solely focused on the examination of the individual situation of the patient, excluding any comparative analysis in a broader context, which would take into account medical needs of other domestic patients. While this approach is fairly common in the adjudication of individual rights, it does not seem suitable for dealing with complex socioeconomic issues, such as the distribution of funds allocated for public healthcare. Where the inquiry focuses on the individual's circumstances, especially when these circumstances relate to serious health issues, 'every human inclination will be to rescue [her] by providing treatment even if its likelihood of success is uncertain'. ${ }^{16}$ However, such inquiry leaves aside those whose treatment may be affected as a result. ${ }^{17}$ Moreover, it allows patients with less urgent medical needs to gain priority over patients with more urgent ones, thus questioning a system's fairness and commitment to equality. ${ }^{18}$

Since the budget allocated by governments to social healthcare is usually not sufficient to allow for the swift provision of treatment to all patients, competent authorities make use of the available resources by planning and setting priorities. ${ }^{19}$ Waiting lists, for instance in the British NHS, reflect those priorities and are intended to maintain fairness and equality between patients who require hospital treatment. ${ }^{20}$ The Court's focus on the individual case of the patient when determining the necessity of treatment clearly interferes with the prerogative of national governments to plan and prioritise healthcare expenditure. Moreover, while benefiting the vocal minority of patients, it diverts resources from 'poorly represented, less visible, less articulate groups, typically composed of disabled, mentally ill and elderly patients'. ${ }^{21}$ As a consequence, the waiting time for those groups of patients, with equally, if not more, urgent needs, but incapable of travelling abroad, will become longer. To avoid

15 Smits and Peerbooms (n 8) para 105; Watts (n 5) para 75.

16 Newdick (n 5) 1650.

17 ibid 1650.

18 Watts (n 5) para 42; Newdick (n 5) 1662.

19 Watts (n 5) para 13.

20 ibid, para 14.

${ }^{21}$ Newdick (n 5) 1646. See also Schiek (n 5). 
this situation and maintain equal access to hospital care, governments would need either to provide additional funding for the healthcare budget, or to restrict the range of treatments available. ${ }^{22}$

Moreover, if the frequency of patient mobility were to significantly increase, the additional financial pressure would arguably hurt most the less economically developed Member States (normally, more recent members of the EU), since patients from these countries would be the most likely candidates to use the benefits of cross-border healthcare. The financial burdens resulting from the poorer Member States having to fund expensive treatment received in the richer ones may exacerbate the already existing inequities among the national healthcare systems, threatening the sustainability of the social security budgets of the less developed Member States and thus contributing to further decline in the quality of healthcare in their territories. ${ }^{23}$ Without an EU-level fund for balancing the extreme inequalities, patient mobility in the EU may sooner or later prove unsustainable. ${ }^{24}$

\subsection{Collectively set labour standards as an obstacle to economic freedoms}

In its case law on collective labour rights, ${ }^{25}$ the CJEU asserts that, in principle, EU law does not preclude the territorial application of national legislation or collective agreements laying down employment terms and conditions. Member States are also free to define conditions of the exercise of collective bargaining and the right to strike. However, in exercising their competences, Member States have to comply with EU free movement rules. ${ }^{26}$ In the Court's interpretation, this means that national labour laws and EU free movement rules are in a hierarchical relationship, whereby the terms and conditions of employment capable of dissuading foreign undertakings from exercising their freedom of establishment or freedom to provide services must be justified as appropriate and necessary in light of the objective of the protection of workers. ${ }^{27}$ Such interpretation significantly narrows down the scope of application of na-

\footnotetext{
22 Watts (n 5) para 42.

23 A Kaczorowska, 'A Review of the Creation by the European Court of Justice of the Right to Effective and Speedy Medical Treatment and its Outcomes' (2006) 12 Eur L J 345, 366367.

${ }^{24}$ Kaczorowska (n 23); Davies (n 5) 125-128.

25 See eg Viking (n 6); Laval (n 6); Case C-346/06 Dirk Rüffert $v$ Land Niedersachsen [2008] ECR I-01989; Case C-319/06 Commission of the European Communities $v$ Grand Duchy of Luxembourg [2008] ECR I-04323; Case C-271/08 Commission v Germany [2010] ECR 00000; Alemo-Herron (n 6).

26 Viking (n 6) para 40, with further references to Decker (n 7) paras 22-23 and Kohll (n 7) paras 18-19.

${ }_{27}$ Viking (n 6) paras 72, 73, 75; Laval (n 6) para 57.
} 
tional labour standards to posted workers and poses a profound challenge to national systems of industrial relations, thus threatening the level of worker protection in the EU.

The Court's application of the proportionality test to assess the legality of strike action, laid down in the seminal Viking and Laval judgments, weakens the position of trade unions vis-à-vis foreign employers. On the one hand, the CJEU acknowledges that the organisation of collective action by trade unions must be regarded as covered by their legal autonomy. ${ }^{28}$ And yet, the proportionality review seems to significantly restrict that autonomy by narrowing down the permissible objectives of strike action to one - securing employment conditions that are under serious jeopardy. ${ }^{29}$ Moreover, the requirement that strike action constitutes the least restrictive means in a given situation ${ }^{30}$ seems to go against the nature of the right to strike and risks compromising the effectiveness of collective bargaining and trade union activity more generally. ${ }^{31}$ Also, this test creates a climate of legal uncertainty. Trade unions can no longer rely on national law to secure the legality of collective action, while EU law makes it conditional on a case-by-case assessment of necessity in relation to EU business freedoms, something that is extremely difficult to predict. ${ }^{32}$ At the same time, due to the direct horizontal effect of articles 49 and 56 TFEU, employers are handed a strong incentive to sue trade unions in courts with a promise of pecuniary compensation. As a result, trade unions are dissuaded from taking collective action given the risks involved, ${ }^{33}$ which significantly weakens their bargaining power and inhibits their ability to protect workers' interests.

Furthermore, the Court seems to be reluctant to accept collective bargaining as a means of laying down the terms and conditions of employment. In the view of the Court, collective agreements - with the exception of those that are universally or generally applicable and lay down the nucleus of employment conditions listed in article 3(1) of the Posted Workers Directive ${ }^{34}$ - create too much uncertainty in the legal framework

\footnotetext{
Viking (n 6) para 35.

29 ibid, paras $77,81$.

30 ibid, paras 87-89.

31 T Novitz, P Germanotta, 'Globalisation and the Right to Strike: The Case for EuropeanLevel Protection of Secondary Action' (2002) 18(1) IJCLLIR 67, 68-69; ACL Davies, One Step Forward, Two Steps Back (n 6) 143; Ewing and Hendy (n 6) 13.

32 C Barnard, 'A Proportionate Response to Proportionality in the Field of Collective Action' (2012) 37 ELR 117, 120-121; P Syrpis and T Novitz, 'Economic and Social Rights in Conflict: Political and Judicial Approaches to their Reconciliation' (2008) 33 EL Rev 411, 418-419.

33 Syrpis and Novitz (n 32) 418-419; Barnard (n 32) 120-121.

${ }_{34}$ Council Directive 96/71/EC concerning the posting of workers in the framework of the provision of services [1997] OJ L18/1 (Posted Workers Directive).
} 
of the transnational provision of services and hence make it excessively difficult for employers to determine the obligations they need to comply with. ${ }^{35}$ These agreements cannot therefore be justified either under the PWD or under article 56 TFEU. Such a position seems to go against the spirit of the Treaty, which has, since Maastricht, affirmed the EU's commitment to promote social dialogue while emphasising respect for the autonomy of social partners and for the diversity of national systems. ${ }^{36}$

By constraining the operational autonomy of trade unions and limiting the scope of collective bargaining, the Court challenges the viability of European systems of industrial relations, particularly in the Member States that rely on autonomous collective bargaining in the implementation of national social policy, such as the Scandinavian states. ${ }^{37}$ In the Scandinavian model, trade unions in principle have the exclusive responsibility to safeguard rather high-average, flexible levels of wages and employment conditions for all different categories of employees..$^{38}$ In the face of the Court's case law, governments must either modify their traditional methods of social regulation, or accept the fact that labour standards set by trade unions will most likely be rejected by the CJEU. A number of countries have already followed the first route, which is problematic in light of the lack of EU competence to regulate collective labour law. ${ }^{39}$

Finally, the Court's position seems to reinforce the idea that social dumping is an acceptable method for businesses to compete in the European market. The working conditions of migrant workers will be governed by labour standards of the least regulative Member State relevant to the situation in question, unless higher standards are able to survive the high-threshold necessity review, save for the nucleus of rules for minimum protection enshrined in the PWD. ${ }^{40}$ Such a position encourages reg-

\footnotetext{
35 Laval (n 6) paras 107, 110. See also Rüffert (n 25) paras 26-29, 39-40.

36 TFEU, arts 151, 152; EC Treaty, arts 136, 138. Also contrast the Viking and Laval judgments with Case C-67/96 Albany [1999] ECR I-5751, paras 59-60.

37 C Joerges and F Rödl, 'Informal Politics, Formalised Law and the "Social Deficit" of European Integration: Reflections after the Judgments of the ECJ in Viking and Laval' (2009) 15 ELJ 1.

${ }^{38} \mathrm{~J}$ Malmberg, The Impact of the ECJ Judgments in Viking, Laval, Ruffert and Luxembourg on the Practice of Collective Bargaining and the Effectiveness of Social Action' (2010) European Parliament Directorate General for Internal Policies, Policy Department A: Economic and Scientific Policy, 7 <http://www.europarl.europa.eu/activities/committees/ studies.do?language=EN $>$ accessed 17 February 2015.

39 J Malmberg and T Sigeman, 'Industrial Actions and EU Economic Freedoms: The Autonomous Collective Bargaining Model Curtailed by the European Court of Justice' (2008) 45 CML Rev 1115; A Bücker and W Warneck (eds), 'Viking - Laval - Rüffert: Consequences and Policy Perspectives' (2010) ETUI Report 111; M Blauberger, 'With Luxembourg in Mind ... The Remaking of National Policies in the Face of ECJ Jurisprudence' (2012) 19 Journal of Eur Public Policy 109, 114-124.

40 S Deakin, 'Regulatory Competition in Europe after Laval' (2008) University of Cambridge CBR Working Paper 364/2008, 18 <http://www.cbr.cam.ac.uk/pdf/WP364.pdf> accessed
} 
ulatory competition between governments, as well as wage competition among businesses and workers. ${ }^{41}$ While encouraging wage competition may be a valid economic policy decision, the Court's asymmetrical position threatens to override the also legitimate aim of Member States wishing to maintain their chosen level of worker protection, challenges the capacity of new Member States to build their own social models, and risks creating a race to the bottom in European labour standards. ${ }^{42}$ Moreover, the legitimacy of judicial decision-making is strained when such extremely political choices are embedded within adjudication.

\section{Institutional balance as a constitutional principle}

The remainder of the paper argues that the Court's case law deviates from the principle of institutional balance, which governs the distribution of powers among the EU institutions, particularly the Council, the Parliament, the Commission, the European Council, and the CJEU. The principle of institutional balance has been mainly discussed in the academic literature in the context of the division of powers between the legislative organs of the EU - the Commission, the Council, and the Parliament. ${ }^{43}$ Institutional balance requires that EU institutions act within the scope of the powers conferred on them by the Treaties (positive obligation) and not encroach on the powers assigned to other institutions (negative obligation). This principle is specific to the EU, but the concept itself is inspired by the principle of the separation of powers applicable in the national legal orders. ${ }^{44}$ However, contrary to the principle of the separation of powers, "the aim of the system of the division of powers between the various [EU] institutions is [exactly] to ensure that the balance between the institutions provided for in the Treaty is maintained, and not to protect individuals' against the abuse of power by the government. ${ }^{45}$

21 November 2012; N Hös, The Principle of Proportionality in the Viking and Laval Cases: An Appropriate Standard of Judicial Review?' (2009) EUI Department of Law Working Paper 2009/06, 16, 19-20 <http://cadmus.eui.eu/bitstream/handle/1814/11259/ LAW_2009_06.pdf> accessed 27 July 2013.

41 Deakin (n 40) 14-15, 20-21; Malmberg and Sigeman (n 39) 1116.

42 'Rüffert Case: ETUC Warns that ECJ's Judgment Is Destructive and Damaging' (ETUC, 3 April 2008) <http://www.etuc.org/a/4830> accessed 21 November 2012.

43 P Craig, 'Democracy and Rule-making within the EC: An Empirical and Normative Assessment' (1997) 3 ELJ 105; Y Devuyst, 'The European Union's Institutional Balance After the Treaty of Lisbon: "Community Method" and "Democratic Deficit" Reassessed' (2008) 39 Georgetown Journal of International Law 249, 306-308; B Smulders and K Eisele, 'Reflections on the Institutional Balance, the Community Method and the Interplay between Jurisdictions after Lisbon' (2012) Research Paper in Law 04 / 2012, College of Europe, Department of European Legal Studies <http://aei.pitt.edu/39285/> accessed 10 January 2016.

44 J-P Jacqué, 'The Principle of Institutional Balance' (2004) 21 CML Rev 383, 384.

45 ibid. See also Case C-282/90 Vreugdenhil BV v Commission [1992] ECR I-1937, paras $20-21$. 
The principle of institutional balance has been enshrined in the Treaties since the creation of the EEC. Article 4 (1) EEC of Part One of the Treaty, titled 'Principles', stated that the tasks entrusted to the Community shall be carried out by its institutions, which 'shall act within the limits of the powers conferred upon [them] by this Treaty'. The current version of this provision, article 13 TEU, maintains the wording almost identical to the original one and adds that that ' $[t]$ he institutions shall practise mutual sincere cooperation'.

The content of the principle was fleshed out by the CJEU as early as in 1958 in the Meroni judgment, ${ }^{46}$ where the Court was asked to decide to what extent EU institutions may delegate their tasks to regulatory agencies. The Court held that the delegation of powers 'can only relate to clearly defined executive powers, the use of which must be entirely subject to the supervision of the [delegating authority]'. ${ }^{47}$ It ruled that the balance of powers was characteristic of the institutional structure of the Community and required the Community institutions to pursue Community goals while acting 'within the limits of their respective powers'. ${ }^{48}$ The Court elaborated on the principle in the Chernobyl case,${ }^{49}$ which concerned an action for annulment brought by the European Parliament and concerning a Council regulation which was allegedly adopted using the wrong legal basis and failing to involve the Parliament through the cooperation procedure. The Treaties did not contain a provision allowing the Parliament to bring an action for annulment in this situation. Regardless, the Court ruled:

The Treaties set up a system for distributing powers among the different Community institutions, assigning to each institution its own role in the institutional structure of the Community and the accomplishment of the tasks entrusted to the Community. Observance of the institutional balance means that each of the institutions must exercise its powers with due regard for the powers of the other institutions. It also requires that it should be possible to penalize any breach of that rule which may occur. ${ }^{50}$

It follows from the judgment that observance of the principle simply requires respecting the framework for the distribution of powers among the EU institutions as laid down in the Treaties.

\footnotetext{
46 Case C-9/56 Meroni \& Co, Industrie Metallurgiche, SpA $v$ High Authority of the European Coal and Steel Community [1958] ECR 00133 (Meroni).

47 Meroni (n 46) 152.

48 ibid 152.

49 Case C-70/88 European Parliament $v$ Council [1990] ECR I-2041 (Chernoby).

50 Chernobyl (n 49), paras 21-22, 26-27.
} 
The question is how one determines the outer limit of the powers of the CJEU. Its mandate under article 19 TEU is formulated extremely broadly, and the performance of the task of ensuring that the law is observed in the interpretation and application of the Treaties certainly entails a degree of discretion and autonomy. AG Trstenjak suggested in her Opinion in the Audiolux case that the principle of institutional balance requires the CJEU to respect the rule-making role of the EU legislature and observe the necessary self-restraint in developing general principles of EU law which might possibly run counter to the legislature's aims'. ${ }^{51}$ This implies that the Court 'may not assume the role of the Community legislature if a gap in the law can be filled by the Community legislature'. ${ }^{52}$ The approach suggested by AG Trstenjak might not be suitable for defining the limits of the Court's action because the Treaty allows overlap between the powers of the Court and the legislature. To illustrate, the Court held in Brasserie du Pêcheur that the principle of institutional balance did not prevent it from recognising in European law a general right to compensation of individuals in the event of breaches of that law. ${ }^{53}$ In the context of the present analysis, there is also the question whether a gap in law exists at all, and consequently whether the legislature is entitled to exercise its rule-making powers. The answer to this question seems to be positive. Where the Treaty excludes the adoption of binding measures in certain areas pursuant to the sectoral legal bases, as is the case with healthcare and collective labour rights, ${ }^{54}$ those areas can nevertheless be subjected to EU legislative action by having recourse to the functionally broad legal bases. ${ }^{55}$ In the majority of cases, these will be article 114, which authorises the adoption of measures that advance the objectives of the internal market, and article 352 TFEU - the 'flexibility

51 Case C-101/08 Audiolux SA e.a v Groupe Bruxelles Lambert SA (GBL) and Others and Bertelsmann AG and Others [2009] ECR I-09823.

52 ibid, para 107.

53 Joined Cases C-46/93 and C-48/93 Brasserie du Pêcheur SA v Bundesrepublik Deutschland and The Queen $v$ Secretary of State for Transport, ex parte: Factortame Ltd and others [1996] ECR I-1029, paras 24-27; K Lenaerts and A Verhoeven, 'Institutional Balance as a Guarantee for Democracy in EU Governance' in C Joerges and R Dehousse (eds), Good Governance in Europe's Integrated Market (OUP 2002) 35, 46.

${ }^{54}$ TFEU, arts 5, 6, 153(7), 168. For examples of other policy areas, see TFEU, arts 84, 165, 167, 173, 195, 196, 197. B Ryan, 'The Charter and Collective Labour Law' in TK Hervey and J Kenner (eds), Economic and Social Rights Under the EU Charter of Fundamental Rights - a Legal Perspective (Hart Publishing 2003) 67-68, 84-85.

55 Case C-491/01 Rv Secretary of State ex parte BAT and Imperial Tobacco [2002] ECR I-11543, paras 84, 86, 106, 123 (Tobacco Advertising); Case C-380/03 Germany v Council and European Parliament (Tobacco Advertising II) [2006] ECR I-11573, para 42; Case C-58/08 Vodafone, O2 et al v Secretary of State [2010] ECR I-04999; Case C-210/03 Swedish Match [2004] ECR I-11893; Cases C-154/04 and C-155/04 Alliance for Natural Health v Secretary of State for Health [2005] ECR I-6451, para 30; S Weatherill, The Limits of Legislative Harmonisation Ten Years after Tobacco Advertising: How the Court's Case Law Has Become a "Drafting Guide"' (2011) 12 German Law Journal 827. 
clause'. Moreover, the Court holds that the exercise of legislative powers on the basis of article 114 entails a broad margin of discretion on behalf of the legislature. ${ }^{56}$ It follows that if we were to accept the approach suggested by AG Trstenjak, meaning that the legislature is entitled to fill in any existing gaps in the regulation of the broad area of the EU's internal market, as a result the Court might be barred from any sort of interference with the legislative mandate. Such a result seems to go against the wording of article 19 TEU, which grants the Court the exclusive authority to interpret the Treaties.

Therefore, given the breadth of the Court's mandate under article 19 TEU as well as the breadth of the legislative mandate under the functional legal bases, a degree of overlap between the powers of the legislature and the Court seems to be both inevitable and constitutionally justified. After all, the Court, as the interpreter of the Treaty, lays down the principles that guide the EU legislature in adopting legislative acts. ${ }^{57}$ When measuring the institutional balance, the task is thus to determine the point when the guidance provided by the Court amounts to a breach of institutional balance. As a minimum requirement, it seems to be unacceptable for the Court to extend its powers to the detriment of the legislature because such practice would create the legal situation that the principle exactly aims to prevent. ${ }^{58}$ The Court appears to endorse this view by holding that the principle of the balance of powers requires that 'the practice of [one institution] cannot deprive the other institutions of a prerogative granted to them by the treaties themselves'. ${ }^{59}$ Accordingly, article 19 does not entitle the Court to exercise its authority to interpret EU law in a way that negates the legislative discretion accorded to the EU legislative institutions. Otherwise, the Court would become a substitute for the political decision maker, thus infringing the principle of institutional balance. ${ }^{60}$

\section{CJEU case law upsets institutional balance}

The following analysis demonstrates how CJEU free movement case law involving areas of healthcare and collective labour law creates an un-

\footnotetext{
56 Tobacco Advertising (n 55) paras 84, 86, 106, 123; Tobacco Advertising II (n 55) para 42.

57 See eg an account on the legislative developments in discrimination law following the Defrenne judgment: D Sindbjerg Martinsen, An Ever More Powerful Court? The Political Constraints of Legal Integration in the European Union (OUP 2015) 67-71.

58 Jacqué (n 44) 384.

59 Case C-149/85 Roger Wybot v Edgar Faure [1986] ECR 02391, para 23.

60 Lenaerts and Verhoeven (n 53) 45-46, referring to Case C-109/75 R National Carbonising Company Limited $v$ Commission of the European Communities [1975] ECR 01193, para 8; Case C-415/85 Commission v Ireland [1988] ECR 3098, paras 8-9; Case C-249/96 Lisa Jacqueline Grant v South-West Trains Ltd [1998] ECR I-00621, paras 35-36, 47-48.
} 
usual inter-institutional dynamic that deprives the legislature of its constitutional prerogative, thus undermining the principle of institutional balance. The case law either prevents the EU's legislature from acting or leaves it with a limited choice of legislative options, essentially confined to those reaffirming and codifying the Court's case law. Consequently, the Court becomes de facto the ultimate institution that makes EU level policy choices binding on the Member States. The legislative measures that best illustrate this dynamic are the draft Monti II Regulation, ${ }^{61}$ the Patients' Rights Directive, ${ }^{62}$ and the Social Security Regulation of $1971 .{ }^{63}$

\subsection{The CJEU pre-empts legislative action}

Proposed on the basis of article 352, the 'flexibility clause', the draft Monti II Regulation was intended to provide a legislative response to the Court's interpretation of the relationship between the EU fundamental freedoms and the right to strike. ${ }^{64}$ Although the draft contained a provision explicitly stating that it was not reversing the Viking and Laval line of case law where the CJEU effectively subordinated the right to strike to the economic freedoms, it did seem to 'correct' the Court's interpretation by explicitly recognising the general equality between the fundamental rights and fundamental freedoms in EU law. ${ }^{65}$ The Proposal stated that

the exercise of the freedom of establishment and the freedom to provide services enshrined in the Treaty shall respect the fundamental right to take collective action, including the right or freedom to strike, and conversely, the exercise of the fundamental right to take collective action, including the right or freedom to strike, shall respect these economic freedoms. ${ }^{66}$

Furthermore, the proposal highlighted the need for the national courts to strike a fair balance in the process of reconciliation of both legal values. Monti II thus appears to have established a double pro-

${ }^{61}$ European Commission, Proposal for a Council Regulation on the exercise of the right to take collective action within the context of the freedom of establishment and the freedom to provide services (Monti II) COM (2012) 130 final.

62 Council Directive 2011/24/EU of 9 March 2011 on the application of patients' rights in cross-border healthcare [2011] OJ L88/45, preamble, recital (21) (Patients' Rights Directive).

63 Regulation (EEC) No 1408/71 of the Council of 14 June 1971 on the application of social security schemes to employed persons and their families moving within the Community [1971] OJ L149/2 (Social Security Regulation, 1971).

${ }_{64}$ Monti II (n 61); The Adoptive Parents, The Life of a Death Foretold: The Proposal for a Monti II Regulation' in M Freedland and J Prassl (eds), EU Law in the Member States: Viking, Laval and Beyond (Hart Publishing 2014) 95 ff.

65 Monti II (n 61), arts 3.4.2 and 3.4.4; Monti II (n 61), Explanatory Memorandum, 10 <ec. europa.eu/social/BlobServlet?docId=7480\&langId=en> accessed 20 May 2105.

66 Monti II (n 61) art 2. 
portionality review as a means of striking an equitable balance between the exercise of the right to strike and the fundamental freedoms, ${ }^{67}$ thus deviating from the sort of balance between the two values adopted by the CJEU in Viking and Laval. Monti II was eventually withdrawn due, at least officially, to the objections raised by national parliaments regarding a breach of subsidiarity and the lack of the EU's legislative competence to regulate collective labour rights. In fact, it was the first time that national parliaments had triggered the 'yellow card' mechanism established by the Lisbon Treaty. ${ }^{68}$

The fate of Monti II shows that the Court's rulings may have the effect of pre-empting any meaningful legislation at the EU level. The more controversial the ruling, the more likely this will be the case. Monti II sought to achieve a more equitable balance in the relationship between the economic freedoms and the right to strike, in this way departing from the position adopted by the Court. However, not surprisingly, the proposal raised some controversial reactions from the stakeholders. The European Trade Union Confederation rejected the Proposal, claiming it was too restrictive on the right to strike, while Business Europe, an association representing more than 20 million European companies, was also against it, but for an opposite reason: Monti II was less favourable to the side of the employers than the Court's rulings. Finally, protecting the national interests, 12 parliaments pulled the 'yellow card', claiming that the Proposal violated the principle of subsidiarity (as article 153 excludes the right to strike from the scope of the EU's competence) and interfered with the national systems of industrial relations. ${ }^{69}$ Due to the objections raised by the national parliaments, the Commission was required to review the proposal, and eventually withdrew it. However, the proposal died not because there were real concerns over subsidiarity - after all, the draft dealt with the interpretation of the free moment rules in cross-border situations. As the Commission admitted in a formal letter addressed to the national parliaments in response to the raised objections, Monti II was withdrawn because it was 'unlikely to gather the necessary political support' to enable its adoption. ${ }^{70}$ This is not surprising given that article 352 requires a unanimous vote in the Council. In the end, although article 352 enabled the adoption of Monti II, the lack of political will for the EU to interfere in national industrial systems, as well as the lack of consensus between the stakeholders, resulted in the withdrawal of the

\footnotetext{
67 Case C-271/08 Commission v Germany [2010] ECR 00000, Opinion of AG Trstenjak.

68 M Goldoni, The Early Warning System and the Monti II Regulation: The Case for a Political Interpretation' (2014) 10 EuConst 90.

69 For a detailed account, see I Cooper, 'A Yellow Card for the Striker: How National Parliaments Defeated EU Strikes Regulation' (2013) Network of European Union Centres for Excellence 5 <http://euce.org/eusa/2013/papers/12g_cooper.pdf> accessed 20 May 2015.

70 Cooper (n 69) 15; Freedland and Prassl (n 64) 96, 99.
} 
proposal. The controversial rulings of the CJEU that triggered the whole process remained unchanged.

On the other hand, the heated debate over Monti II in a way was 'much ado about nothing'. Even if adopted, the regulation could in principle not have replaced the Court's particular interpretation of the free movement rules. As an interpretation of primary law, it is superior to legislation, national or EU-wide, and remains intact as long as the Treaty remains unamended. In other words, the rules developed in Viking and Laval would have continued to apply, as a matter of law, even if Monti II had gained a unanimous vote. The only possible scenario where Monti II could have had a real impact after adoption is if the Court was willing to temper its position as a sign of respect to the political consensus. However, it is difficult to predict how likely this outcome would be, especially since the Court had in the past gone against the express wishes of the legislature even where the legislation had gained unanimous support in the Council. The latter phenomenon is discussed in the following section.

\subsection{The Court prevents legislative overturn}

Another way in which the Court shapes the institutional dynamic is through interpreting existing EU legislation to arrive at a meaning that serves the objectives of free movement. The Court's interpretation of article 22(2) of the Social Security Regulation of $1971^{71}$ best illustrates this tendency.

The objective of Regulation 1408/71 was to establish rules on the coordination of the national social security systems. ${ }^{72}$ The original wording of the Regulation accorded Member States a considerable margin of discretion in making decisions regarding the grant of authorisation to receive medical treatment abroad that is subsequently to be reimbursed by the patient's Member State of affiliation. The authorisation could not be refused 'where the treatment in question cannot be provided for the person concerned within the territory of the Member State in which he resides'. The provision was phrased in rather general and broad terms, unqualified by references to either the timing or effectiveness of the treatment. It gave a lot of leeway to the national healthcare authorities to assess whether, in principle, they were capable of providing the treatment in question.

The Court had the opportunity to deliver its interpretation of article 22(2) in the Pierik cases, ${ }^{73}$ concerning a Dutch national who went to Germany to receive hydrotherapy treatment. The patient's request for

71 Social Security Regulation, 1971 (n 63).

72 ibid, preamble.

73 Case C-117/77 Pierik I [1978] ECR 825; Case C-182/78 Pierik II [1979] ECR 1977. 
reimbursement was refused because hydrotherapy was not among the types of treatment covered by Dutch health insurance. The Court held that the intention of the Regulation was to give medical requirements the decisive role in the decision of the competent authorities to grant or refuse the authorisation for treatment abroad. Therefore, authorisation could not be refused when the foreign treatment was considered 'necessary and effective', even if it was not offered in the health package of the state of insurance. ${ }^{74}$ The Court's judgments received immediate political response at the EU level. Fearing that the sustainability of their healthcare budgets might be jeopardised, Member States 'corrected' the Court's interpretation by adopting unanimously several amendments to the Regulation. ${ }^{75}$ Article 22 was amended to include a provision expressly stating that authorisation cannot be obtained for treatment that is not among the benefits provided for by the legislation of the patient's Member State of residence. ${ }^{76}$ If this condition is fulfilled, prior authorisation could not be refused where the patient could not be given adequate treatment in her state of affiliation within the time normally necessary for obtaining such treatment, taking account of the patient's state of health and the probable course of the disease.${ }^{77}$ Also, a new recital was introduced in the preamble. Referring to the 'experience' of Directive 1408/71, it emphasised the importance of extending the discretionary power of an institution of a Member State ... in granting or refusing authorization'. Quite apparently, the purpose of the amendments was to regain the prerogative that Member States had in making decisions about public healthcare before interference in the process by the CJEU.

In the later judgments, the Court did not challenge the position of the Member States regarding the scope of treatment covered by article 22. Yet, it did maintain an expansionist interpretation of the article by giving a Europeanised meaning to terms that are key in defining the scope of the benefits package ${ }^{78}$ and providing an extremely detailed interpretation of the 'medical necessity' criterion, ${ }^{79}$ largely excluding the broader objec-

\footnotetext{
74 Pierik I (n 73) para 26; Pierik II (n 73) paras 12-13.

75 See eg Council Regulation (EEC) No 2793/81 of 17 September 1981 amending Regulation (EEC) No $1408 / 71$ on the application of social security schemes to employed persons and their families moving within the Community and Regulation (EEC) No 574/72 fixing the procedure for implementing Regulation (EEC) No 1408/71 [1981] OJ L275, art 22(2) (Regulation 2793/81); V Hatzopoulos, 'Actively Talking to Each Other: The Court and the Political Institutions' in B de Witte, E Muir and M Dawson (eds), Judicial Activism at the European Court of Justice (Edward Elgar Publishing 2013) 135; A P Van der Mei, Free Movement of Persons Within the European Community: Cross-Border Access to Public Benefits (Hart Publishing 2003) 254-256.

76 Regulation 2793/81 (n 75) preamble and art 22 (1).

77 ibid.

78 Smits and Peerbooms (n 8) para 94.

79 Watts (n 5).. ra 53, 55, $57-61 ; 2015$ () 10ty provisions, such as eciate
} 
tives of healthcare systems. In this way, once again the Court minimised the margin of discretion bestowed on the Member States by the Regulation.

Moreover, in the Watts judgment, concerning the reimbursement by the UK authorities of a hip replacement surgery performed in France, the Court unequivocally concluded that there was 'no reason which seriously justifies different interpretations' of the 'undue delay' criterion depending on whether the context is article 22 of the Social Security Regulation or article $49 \mathrm{EC}$. This meant that the Court's interpretation of secondary law was elevated to the status of primary EU law. ${ }^{80}$ The intention of the legislature expressed in the Social Security Regulation was thus shaped and moulded in order to fit the logic of the free movement rules. Moreover, having based its position on both the Regulation and the Treaty, the Court also precluded the possibility of a legislative amendment overturning this interpretation. Despite political resistance, the Court ended up drastically changing the meaning of article 22 of Regulation 1408/71 and turned it into an EU-wide binding obligation requiring Member States to reimburse the costs of medical treatment received abroad to patients whose condition was serious enough to necessitate the treatment.

The Social Security Regulation is not an isolated example of an expansive, market-oriented interpretation adopted by the CJEU. The widely discussed Posted Workers Directive has been interpreted by the Court as a maximum harmonisation measure as far as working conditions are concerned, regardless of the fact that it was commonly interpreted as a minimum harmonisation directive establishing a floor of rights for posted workers. ${ }^{81}$ The terms of the directive itself suggest, though, that it is a minimum harmonisation measure. Recital 22 of the preamble emphasises that the directive is 'without prejudice to the law of the Member States concerning collective action to defend the interests of trades and professions'. In addition, article 3(7) explicitly states that paragraphs 1 to 6 - that set out the core of the working conditions applicable to posted workers - 'shall not prevent application of terms and conditions that are more favourable to workers'. ${ }^{82}$ Notwithstanding these stipulations, the Court concluded in Laval that the level of protection that must be guaranteed to workers posted to the territory of the host Member State is limited, in principle, to that provided for in article $3 .^{83}$

\footnotetext{
80 ibid, paras 60, 62, 68 .

81 Rüffert (n 25) Opinion of AG Bot, para 83; Malmberg (n 38) 7; Malmberg and Sigeman (n 39) 1116.

82 Council Directive 96/71/EC concerning the posting of workers in the framework of the provision of services [1997] OJ L18/1, art 3 (Posted Workers Directive).

83 Laval (n 6) para 81.
} 
The Court followed the same pattern when interpreting the Public Procurement Directive of 2004 (PPD) ${ }^{84}$ and the Acquired Rights Directive (ARD) in other cases concerning collective labour rights. ${ }^{85}$ Despite the fact that the PRD expressly authorises the introduction of social policy clauses in public tenders, the CJEU concluded in Rüffert that this did not, however, include the application of collective agreements for regulating questions relating to retirement benefits. ${ }^{86}$ Similarly, in the recent Alemo-Herron case, concerning the transfer of undertakings, the Court came to the conclusion that the ARD, widely interpreted as a minimum harmonisation directive whose main purpose was to protect workers in the event of the transfer of undertakings, ${ }^{87}$ required a balancing between the interests of businesses and workers. ${ }^{88}$ As expected, this balance resulted in prioritising the former over the latter ${ }^{89}$ In particular, it required that the transferee was in a position allowing it 'to make adjustments and changes necessary to carry on its operations' after transfer from the public sector to the private sector..$^{90}$ In this connection, the Court held that clauses providing dynamic contractual rights clauses (such as those referring to applicable collective agreements) are liable to limit considerably the room for manoeuvre necessary for a private transferee' to make such adjustments and changes, hence they are 'liable to undermine the fair balance' between the interests of the transferee and those of the employees. ${ }^{91}$ As a result, the directive was interpreted as precluding the enforceability of the dynamic clauses in cases where the transferees were not provided with the possibility of participating in the post-transfer negotiation processes.

\footnotetext{
84 Council Directive 2004/18/EC on the coordination of procedures for the award of public works contracts, public supply contracts and public service contracts [2004] OJ L134/114, preamble, recital 46, art 26 (Public Procurement Directive 2004/18/EC); Rüffert (n 25).

85 Council Directive (EC) 23/2001 on the approximation of the laws of the Member States relating to the safeguarding of employees' rights in the event of transfers of undertakings, businesses or parts of undertakings or businesses [2001] OJ L82/16 (Acquired Rights Directive).

86 Rüffert (n 25).

87 Acquired Rights Directive (n 85), preamble, art 8. See also Alemo-Herron (n 6), Opinion of AG Cruz Villalón, para 20; J Prassl, 'Freedom of Contract as a General Principle of EU Law? Transfers of Undertakings and the Protection of Employer Rights in EU Labour Law: Case C-426/11 Alemo-Herron and others v Parkwood Leisure Ltd' (2013) 42 ILJ 434; S Weatherill, 'Use and Abuse of the EU's Charter of Fundamental Rights: On the Improper Veneration of "Freedom of Contract". Judgment of the Court of 18 July 2013: Case C-426/11, Mark Alemo-Herron and Others v Parkwood Leisure Ltd' (2014) 10 ERCL 167.

88 Acquired Rights Directive (n 85) arts 3(1) and 3(3); Alemo-Herron (n 6) paras 25-27.

89 Alemo-Herron (n 6) paras 28-30.

90 ibid, paras 25-27.

91 Alemo-Herron (n 6) paras 28-29.
} 


\subsection{The Court predetermines the content of legislation}

The example of the Patients' Rights Directive demonstrates that the legislative measure that has the greatest likelihood of being successfully adopted at the EU level will be the one that essentially replicates the Court's reasoning.

The adoption of the Patients Rights Directive ${ }^{92}$ has been seen by some as a significant step marking the EU's involvement in domestic healthcare policies of the Member States. ${ }^{93}$ Adopted on the basis of articles 114 and 168 TFEU, the directive harmonises national rules on the reimbursement of costs of cross-border healthcare. Its adoption was long anticipated and came five years after an unsuccessful attempt by the Commission to include healthcare services into the Services Directive. ${ }^{94}$ The reason why healthcare was excluded from the Services Directive was the objection by the health policy stakeholders to the largely economic logic embedded in the directive. The stakeholders argued that the country of origin principle enshrined in the Commission's initial proposal ${ }^{95}$ was not an appropriate means to regulate the healthcare sector, which by its nature necessitated a high level of regulatory intervention and control by national governments. ${ }^{96}$

The legislative proposal dedicated specifically to cross-border healthcare was meant to provide a comprehensive legal framework on matters of cross-border healthcare, while also striking a balance between the economic and social dimensions pertaining to the sector. ${ }^{97}$ Not incidentally,

92 Council Directive 2011/24/EU of 9 March 2011 on the application of patients' rights in cross-border healthcare [2011] OJ L88/45, preamble, recital (21) (Patients' Rights Directive).

93 W Sauter, 'Harmonisation in Healthcare: The EU Patients' Rights Directive' (2011) TILEC Discussion Paper No 2011-030 <http://papers.ssrn.com/sol3/papers.cfm?abstract_ id=1859251> accessed 20 May 2015 .

94 Council Directive 2006/123/EC on services in the internal market [2006] OJ L 376/36, preamble, recital 23, art 2(2)(f).

95 ibid, art 16.

96 European Health Policy Forum, 'Recommendations on Health Services and the Internal Market', 26 May 2005, 15 <http://ec.europa.eu/health/archive/ph_overview/health_forum/docs/recom_health_services.pdf> accessed 20 May 2015. For an in-depth discussion, see W Gekiere, R Baeten and W Palm, 'Free Movement of Services in the EU and Health Care' in E Mossialos and others (eds), Health Systems Governance in Europe: The Role of European Union Law and Policy (CUP 2010) 487-504.

97 Commission, 'Proposal for a Directive of the European Parliament and of the Council on the application of patients' rights in cross-border healthcare' COM (2008) 414 final, Explanatory Memorandum, 2 (Proposal for PRD); Commission, 'Consultation regarding Community action on health services' (Communication) SEC (2006) 1195/4; Committee on the Internal Market and Consumer Protection, 'Motion for a European Parliament Resolution on the impact and consequences of the exclusion of health services from the Directive on services in the internal market' (2006/2275(INI)); Sauter (n 93) 7-8; Gekiere, Baeten and Palm (n 96) 499-500. 
the proposal was ambitiously titled by the Commission a directive on 'Patients' Rights', suggesting the creation of EU-wide rights to patients - a concept supposed to be much broader in scope than simply the reimbursement of cross-border medical treatment. ${ }^{98}$ The ambition of the directive is also evidenced by the reference in the preamble and article 5 to the 'overarching values' common to the health systems across Europe - universality, access to good quality care, equity and solidarity. These values are to be observed by the national authorities in providing crossborder treatment. ${ }^{99}$ The idea itself is based on the Council Conclusions on Common Values and Principles in EU Health Systems. ${ }^{100}$

The following argues that, despite the ambitious title and some aspirational rhetoric about the common values of European healthcare, in reality the directive did not do much more than codify the rules already developed in the case law of the CJEU, simply adding to the legal certainty of the current regulatory regime. The directive did not create, nor did it intend to create, any new rights for patients. The Explanatory Memorandum specifies that the objective of the directive is to provide sufficient clarity about the rights to be reimbursed for healthcare provided in other Member States in order to enable patients to exercise those rights in practice, whilst ensuring the observance of the necessary requirements for high-quality, safe and efficient healthcare. ${ }^{101}$ According to recital (10) and article $1(1)$, the directive aims to establish rules for facilitating access to safe and high-quality cross-border healthcare and to promote cooperation on healthcare between Member States. ${ }^{102}$ The directive also seeks to provide 'greater legal certainty' as regards the reimbursement of healthcare costs for both patients and healthcare providers. Recital (8) seems to clarify what lies behind these stipulations by expressly stating that the directive intends 'to achieve a more general, and also effective, application of principles developed by the Court of Justice on a case-bycase basis'. ${ }^{103}$ In line with this logic, a number of provisions pointing to the aims of the directive, as well as those setting out the rules on reimbursement, are qualified by references to the case law of the CJEU, such as 'in accordance with the principles established by the Court of Justice' or 'according to the constant case-law of the Court of Justice'. ${ }^{104}$

\footnotetext{
98 Sauter (n 93) 8-9.

99 Patients' Rights Directive (n 92), preamble, recital 12, art 5.

100 Council, 'Council Conclusions on Common values and principles in European Union Health Systems' [2006] OJ C146/1.

101 Proposal for PRD (n 97), Explanatory Memorandum 7.

102 ibid, recital 10, art 1(1).

103 Patients' Rights Directive (n 92), preamble, recital 8.

104 ibid, preamble, recitals 10, 12, 27, 38, 40, 42, 44, 46, art 1(1).
} 
The terms governing access to and reimbursement of the costs of cross-border healthcare seem to replicate the rules developed by the Court, often even its exact wording. For example, article 7 obligates the Member State of affiliation to cover the costs of cross-border healthcare up to the level of costs that would have been assumed by the Member State of affiliation had this healthcare been provided in its territory, without exceeding the actual costs of the healthcare received. Article 8 establishes the general validity of the prior authorisation requirement for intramural care and lays down the procedural and substantive requirements applicable to the prior authorisation procedure, in accordance with the case law of the CJEU. The authorisation cannot be refused if the treatment cannot be provided on its territory within a medically justifiable time limit, as defined by the Court.

The so-called new elements introduced by the directive - those going beyond the rules developed by the CJEU - essentially concern the procedural guarantees aimed at ensuring that the system of cross-border provision of healthcare and subsequent reimbursement is effective in practice. The new rules include provisions on access to information, transparency of procedures, safety and quality of treatment, and cooperation measures, including information exchange through the national contact points and the E-Health system. ${ }^{105}$ Member States are required to provide healthcare quality and safety standards to ensure patients' access to the information necessary for making informed choices regarding their healthcare, to put in place a complaints procedure for seeking remedies, to respect patients' privacy when processing personal data, and others. Notably, one could argue that these procedural guarantees are anyway required under the free movement law, but at least the directive makes them concrete. Apart from introducing these guarantees and adding to the clarity and certainty of the regulatory framework, the Patients' Rights Directive does no more than give a legislative expression to the substantive rules that have already been in force for a while by virtue of the Court's case law.

The prolonged adoption history of the PRD illustrates the main problem with the adoption of EU-level legislative measures when the issues at hand are politically sensitive and often characterised by diverse regulatory models across the Member States - a problem that Scharpf refers to as the 'joint decision trap'. ${ }^{106}$ When the Treaty rules require a major-

\footnotetext{
${ }^{105}$ Patients' Rights Directive (n 92), see eg arts 4, 5, 9(1) 6, 10, 14, 15; Proposal for PRD (n 97) Explanatory Memorandum 11-12, 17-20.

${ }^{106}$ FW Scharpf, 'The Joint-Decision Trap Revisited' (2006) 44 Journal of Common Market Studies 845; FW Scharpf, 'Negative and Positive Integration in the Political Economy of European Welfare States' in G Marks and others (eds), Governance in the European Union (SAGE Publications 1996); FW Scharpf, 'Community and Autonomy: Multi-level Policymaking in the European Union' (1994) 1 Journal of European Public Policy 219.
} 
ity vote to adopt legislation, Member States with more liberal regimes or smaller budgets can gather enough votes to veto legislative initiatives that would impose more demanding social regulations. This resistance is likely to be supported by national populations, which usually favour the continuation of existing systems of social protection and tend to resist major structural changes. Scharpf argues:

[v]oters in Britain simply could not accept the high levels of taxation that sustain the generous Swedish welfare state; Swedish families could not live with the low level of social and educational services provided in Germany; and German doctors and patients would unite in protest against any moves toward a British-style National Health Service. ${ }^{107}$

Moreover, harmonisation, as a legislative technique, may not offer adequate solutions. For instance, as suggested in section 2, what is necessary for patient mobility to be fully effective is an EU budget for crossborder healthcare. However, as this type of legislative measure does not entail harmonisation, the appropriate legal basis to be used would be the sectoral one, yet it explicitly excludes the option of binding measures. Admittedly, article 352 TFEU could be invoked to adopt innovative legislative solutions, as it empowers the EU to take action in cases where no other Treaty provision provides the necessary powers. However, as the drafting history of Monti II shows, even if competence under article 352 could be shown to exist in principle, any meaningful initiative on behalf of the Commission could be easily trumped by a single veto.

\section{Conclusion}

The paper shows how the Court's case law concerning cross-border healthcare and collective labour law encroaches on the scope of the EU's legislative activity to the degree of upsetting the principle of institutional balance. The argument advanced in the paper seems also to illustrate a broader point that the Court's interference in policy areas that are reserved by the Treaty predominantly for the competence of the Member States is liable to distort the balance of powers between the EU's legislature and the judiciary. The policy issues decided by the case law cannot be further dealt with by EU legislative action because of the constitutional constraints and the ensuing lack of political consensus on the matter, general political resistance against the EU's involvement as such, or because the Court can at any time reinterpret the legislative measure in light of the primary economic rules in a way that will render EU-level

${ }^{107}$ FW Scharpf, 'The European Social Model: Coping with the Challenges of Diversity' (2002) 40 JCMS 645, 652. 
legislative choices devoid of practical force. In these circumstances, legislative measures that have the greatest likelihood of being successfully adopted at the EU level are the ones that essentially replicate the Court's case law. This inter-institutional dynamic caused by the Court's case law appears to work to the detriment of the EU legislature. It deprives it of its law-making prerogative and thus undermines the EU law principle of institutional balance. 